PRZEGLĄD BIBLIOTECZNY 2019

e-ISSN 2545-2487

JADWIGA WOŹNIAK-KASPEREK

Faculty of Journalism, Information and Book Studies

University of Warsaw

e-mail: jbwozniak@uw.edu.pl

ORCID: 0000-0002-1600-3914

\title{
INFORMATION SCIENCE UNDER THE CONDITIONS CREATED BY THE NEW CLASSIFICATION OF FIELDS AND SCIENTIFIC DISCIPLINES: OPENING A BALANCE SHEET
}

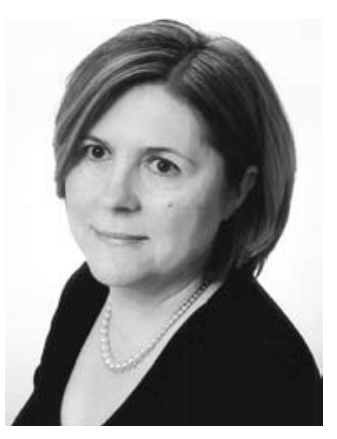

JADWIGA WOŹNIAK-KASPEREK, professor of humanities, head of the Chair of Bibliography and Documentation at the Faculty of Journalism, Information and Book Studies of the University of Warsaw. Research interests: terminological information; information representation, organization and retrieval; users and use of information; bibliography theory. Major publications: with Bartłomiej Włodarczyk, Jezyk haseł przedmiotowych Biblioteki Narodowej: od analizy dokumentu do opisu przedmiotowego (Language of subject headings of the National Library: from document analysis to subject description) (Warsaw: SBP Publisher, 2017); Kłamstwo i metoda: na przykładach reprezentacji treści w katalogach bibliotecznych $i$ w bibliografiach (The Lie and the Method: on examples of content representation in library catalogues and in bibliographies) (Warsaw: BEL Studio, 2018); with Bożena Koredczuk, „Book Studies and Information Science Within Media and Social Communication Studies: The Differentiation or Complementarity?" Studia Medioznawcze 2019, vol. 20, no. 3, pp. 212-224; https://studiamedioznawcz.eu/index.php/studiamedioznawcz/article/view/124/89).

KEYWORDS: Classification of fields and scientific and artistic discipline. Information science. Research Areas. Poland.

ABSTRACT: Objective - Recapitulation of the specific nature of information science and information research undertaken in the conditions of the reorganization of academic life in 
Poland after the introduction of a new classification of fields and scientific and artistic discipline by the Ministry of Science and Higher Education. Methods - A method of analysis and criticism of the literature was used. Results and conclusions - (1) actions are necessary to strengthen the status of information and book studies as a sub-discipline of media and social communication studies; (2) There is a need to open all parties to conscious and critical search for new common areas and research problems. Originality and cognitive value - Discussion about the status and future of the sciences of social communication and media and their components is now an urgent and inalienable need of the academic community if we want to improve the quality of research and strengthen our position within the Polish system of sciences and in a new discipline.

For years, there has been a dispute between supporters of Karl Popper, Thomas Kuhn and Paul Feyerabend about the mechanisms of scientific development. Is science developing due to internal logic or due to external factors? Is development occurring through the accumulation of results obtained or through a revolution related to a radical change in the paradigm? Should it be studied by philosophers of science or rather by sociologists, historians, psychologists? Or maybe the future of science lies in Feyerabendian epistemological anarchism and "anything goes" as a cognitive principle? An interesting suggestion to partially answer these questions is Michał Heller's non-linear concept of science. According to Heller, the theory cannot be completely separated from observation, as well as from meta-scientific reflection. The sequence of events is subject to interpretation, and the adopted method largely determines the results obtained. Therefore, if one approaches the problem using historical and sociological methods, then the natural consequence will be a tendency towards scientific revolutions and external conditions in the development of science, as Kuhn concluded after his thorough research of historical sciences. However, if logical and analytical methods are used, the consequence will be a belief in the logical development of science. Disputes over the classification of sciences overlap with this debate about the essence of science and its developmental mechanisms. Even a cursory review of the classification of sciences, from ancient to modern, proffers the observation that the classification of sciences at different times has distinguished different areas and detailed sub-areas of the sciences according to different criteria. Without diminishing the importance of the classification of sciences, we must not forget, however, that they are entities built on scientific knowledge and, as Tadeusz Kotarbiński once said, one of the main sources of interest in the classification of sciences has long been the librarians' concern for order in libraries. Science is classified as a result of metascientific reflection, but also as a result of administrative actions. The latter situation is currently occurring in Poland in connection with the introduction by the Ministry of Science and Higher Education of a new classification of fields of science, scientific disciplines and artistic disciplines. The 
new classification provokes and forces the creation of a "balance sheet", a kind of inventory of possessions in this first period of taming the new reality.

There are many different divisions of the sciences tailored to specific purposes. Divisions are different due to funding criteria, different research priorities, different ways of awarding degrees and titles and so forth. The classification of a science does not prejudge the quality of scientific research, but it does have some impact on research. It shapes the paths of scientific careers, affects whether or not they are supported, impacts cooperation between researchers, creates a context for the evaluation of scientific research, makes certain sources of financing available or not, etc. Will the Ministry of Science and Higher Education's transfer of information and book studies to the social sciences limit opportunities to apply for funding for projects from the National Humanities Development Program? These questions arise often, but they are not the subject of this paper. The current organizational solution being implemented, that is, the decision that book and information studies should be seen as a component of the social communication sciences and media in the field of the social sciences ${ }^{1}$, causes a dangerous situation in which we may lose some existing objects - cultural objects - from our field of study as well as the influence of culture on "our" research objects. Book and information studies, media and cognitive studies cannot be separated from reflection on culture and cultural institutions. This should be a common concern for both researchers and science managers.

One of the versions of the division which is used mainly for financing science is the OECD (Organization for Economic Co-operation and Development) classification adopted in Poland in a modified form by the aforementioned decision of the Ministry. Currently, science in Poland is divided into fields, which in turn are divided into disciplines, within which specialties or in some cases sub-disciplines can be distinguished, along with further research areas, problems, and issues. In the ministerial classification, the discipline we are interested in here, until recently independent and known under the name of book and information studies, found itself in the social sciences as one of the three components that contribute to the science of social communication and media. These three components are: book and information studies, media studies and cognition, and social communication sciences. The emergence of a new discipline (the science of social communication and media) creates new opportunities, but also new threats, among others the danger of the marginalization or

\footnotetext{
${ }^{1}$ Until the entry into force of the Regulation of the Minister of Science and Higher Education of 20 September 2018 on the fields of science and scientific disciplines and artistic disciplines (http:// www.dziennikustaw.gov.pl/DU/2018/1818/1), book and information science was an independent scientific discipline in the field of humanities.
} 
even disappearance of certain specialties or research areas. The temptation to self-define a new discipline only from the position of one of the three "sub-disciplines" is both large and dangerous. Its name should stimulate reflection and perhaps action towards change.

There is a functional relationship between the media and social communication explaining the name of this new discipline. But the new discipline is not just about 'media in social communication'. Following a different path, it should be noted that placing the terms 'social communication' and 'media' in a logical alternative opens the boundaries of the discipline broadly, without further specifying it, which runs the risk of blurring it. The first part of the name (social communication) is so effective in attracting attention that students of various sciences and specialties are already starting to apply the standards of social communication and media sciences to their fields. This raises the danger of eclecticism, loss of coherence, and loss of the specificity of the discipline and its components. Sub-disciplines of the sciences of social communication and the media or its specialties, as someone else might say, must define their place in this new configuration. I am not talking about entrenching one's own positions, but rather about articulating the specifics in an open, inviting research perspective. The first step can and should be a better, deeper mutual knowledge, which leads us to recall the image of one of the components, which is past information and book studies, to seek out the hard core of this research. In this paper I will reflect only from the perspective of the former information science, directing readers more interested in the book studies aspect to the article by Bożena Koredczuk (Koredczuk, 2019).

Both book and information studies originate from bibliography and librarianship, where research practices were in place long before the constitution of a scientific discipline. Bibliography and librarianship provide a historical but still valid canon of research from which other powerful research branches have grown. Today, library research covers, among others, issues of library organization and management, information education, education in the use of libraries, quality analysis of libraries (including digital ones) and repositories (Głowacka, 2017). It is hard to imagine a sustainable development of the social communication sciences and media without bibliographic and library studies, not to mention the cognitive and social losses. As Barbara Sosińska-Kalata wrote: “The view is widely accepted that information science has developed from issues related to information activities cultivated in the context of bibliography and librarianship" (Sosińska-Kalata, 2017, p. 313). If the development of social communication and media sciences is to be complete, then all components will have to participate, including bibliographic research, library science, book studies research as well as information research. 
The genesis of information science is associated with changes in the production and distribution of scientific literature in the second half of the nineteenth century. In order to master the increasing literary production, analytical bibliographies began to be developed, specialized information services were established in large scientific libraries and research institutes, bibliographic centres, and later documentary centres were formed at institutes, colleges and industrial laboratories. It is impossible not to mention the International Bibliographic Institute, founded in Brussels in 1895 , which gave rise to the organization of the bibliography specialists community, followed by the spread of documentation and information on a global scale. Since the 1950s we have been concerned with information activities being tied with the use of computers. The decade of the 1960s saw the creation of large specialized information systems, including bibliographic databases for individual fields: Chemical Abstracts, INSPEC, MEDLARS (then MEDLINE), BIOSIS, etc. It was also a time of intensive demand for information professionals. The 1980s and the spread of microcomputers and then personal computers resulted in the emergence of a new type of information user - the nonprofessional end user - which today is one of the most important subjects of interest in information science. The widespread use of ICT and, in particular, the Internet since the 1990s has expanded the research field of information science. And the new millennium, along with the even more dynamic dissemination of ICT, mass digitization and the Internet as the main communication medium, introduced into the conceptual and research canon of information science digital immigrants and digital natives, mass dissemination of information using mobile devices, visual communication, the Internet of Things (IoT), collective intelligence, big data, and many other categories.

\section{THE SUBJECT OF INFORMATION SCIENCE RESEARCH}

Information science studies the theoretical and practical aspects of information activity, the overall problems of effective transmission of information and knowledge from the source (asset) to the recipient (user), taking into account social, cultural, psychological and practical factors affecting this transmission. Researchers are interested in methods and tools of information activities, including, but not limited to, information systems, information sources, information processes, methods and tools for their implementation, as well as users of information and their behaviour in various situations and processes, including the process of searching and searching for information. The spectrum of information that is of interest to information scientists today includes not only information on the results of research (scientific information), but also concerning professional life, management, the public, health, business, everyday life, etc. 
The subject of investigation is materialized information (together with its carrier), which is part of the previously mentioned transfer processes, including scientific, social and public communication. It is information science studies communication in its mediational aspect: what people do with information, using which methods, tools, or means, and what information does or can do with people. In other words, in the area of information science research, communication is considered from a specific intermediary (mediational) perspective. A factor in the transmission of information and knowledge, as well as the implementation of information processes, is computer technology along with the so-called intellectual technologies, for example as used to represent knowledge. From the very beginning, the research paradigm of information science has been of a consolidative nature, unifying the computer science current with an understanding of human information needs and behaviour, individual and social practices related to the search and use of information and knowledge. As a result, two approaches are characteristic of research in the domain of information science, both highlighting the aspect of mediation between the area of information and knowledge transfer, i.e. an approach with a humanistic and social attitude, and the IT and technical approach. "[T]he results of research conducted in these two currents should interact, research conducted in one should use the results obtained in the other and inspire undertaking new problems" (Sosińska-Kalata, 2017, p. 316). In practice, this balance is not always maintained, leading to false images of information science research.

The mediational model mentioned above (between the individual and resource records for finding information/knowledge, with a special place therein for the book) is rooted in human cultural and social environments, and as a subject of research cannot be isolated from the influence of this environment. Information science is also interested in information representation, the use of various codes for its effective transmission, storage, and retrieval, as well as devices, ways, and methods of processing and transmission. The science of information has a comprehensive, though heterogeneous nature, deriving, among others, from linguistics, psychology, sociology, philosophy, management, mathematics, statistics, logic, and computer science. "It is a conglomerate of research subfields, different in terms of recognition, objective weight and potential durability. What connects them, or more precisely should connect them, is the perception of the universe of information as a holistic system, whose individual elements are, in their existence and properties, dependent on the entire universe, and on harder or more predictable changes in the conditions initiating information processes and activities. Information science holism is fostered by inter- and transdisciplinary research" (Woźniak-Kasperek, 2015, p. 144). It is necessary to add that information science does not deal 
with all objects, processes, or information events, for example, it does not deal with mass information, or information in the mind of the human being, not externalized, unfixed.

Many Polish authors have spoken about the subject of information science research, presenting different views (Cisek, 2002; Cisek, 2009; Cisek, 2013; Sosińska-Kalata, 2013, Sosińska-Kalata, 2017; Woźniak-Kasperek, 2015). Sabina Cisek formulated interesting observations in an attempt to explain this situation. "First of all, the world of information has undergone far-reaching transformations in recent years, i.e. the area we have studied has changed significantly, which naturally inspires us to rethink the mission, issues and assumptions of the discipline. Secondly, mediation in the social world of information, which is the axis of our considerations, is multifaceted, has an educational, institutional, communicative, cultural, organizational, political, legal, psychological, social, technological (today mainly IT) and utilitarian dimension. It is also possible to understand objects, processes, events and information phenomena differently; it is not so easy to specify what fixed information resources are, and even more difficult to specify information needs and behaviours. Thirdly, information science by its very nature integrates what is physical/material (carriers, technology), mental (information users) and ideal (information as such, knowledge of humanity), individual and social, subjective and objective. It is not easy to include in the formulation of the subject of research. Fourthly, there have been various concepts of information science and paradigms within it for years" (Cisek, 2013). An issue that would horizontally connect disciplines federated in the sciences of social communication and the media is that of subject-related social communication, with a certain conceptual approach that also includes scientific communication implemented using digital devices, inscribed in the broad context of information, book, and media culture.

\section{IMPORTANT AREAS OF RESEARCH}

From the literature on information science a picture emerges of a discipline whose most important research category is information itself and related areas, among which the organization of information and knowledge as well as information and knowledge management occupies a prominent place. Next to it are others, such as: research on users and their behaviour (information behaviours in various domains, including fields of knowledge; information behaviours in everyday life; in the conditions of information overload, searching for information and its use; information barriers); information technology; information architecture; bibliometrics, informetrics, webometrics, altmetrics (Kowalska, 2017). 
The organization of information and knowledge (OIK) has traditionally focused on such types of documents as books, articles, maps, patent descriptions, legal documents, photographs, music and film recordings, etc. The development of the digital environment has resulted in current research covering issues of organizing access to digital collections of various types of documents and artefacts stored in GLAM institutions (Galleries, Libraries, Archives, Museums) and information resources for various types of public and commercial activities (access to public, health, business information and services, organizational information, commercial, etc.). On the basis of the OIK, models of OIK processes and knowledge organization systems are created. Processes involve transforming information representations. In turn, knowledge organization systems are tools that are used to organize access to stored content. These are all types of metadata schemas used to organize information and support knowledge management, especially in a network environment. In a narrower sense, in particular with regard to traditional indexing and classifying tools used in libraries, the name information organization system is also used. The OIK area includes, among others, specific issues such as: metadata and their application; knowledge organization systems, including ontologies and semantic technologies; information and search languages; automatic classification and clustering; information organization systems; organization of business and corporate information; visualization.

Information management, in turn, means the organization and control of information resources, their processing and delivery to specific recipients, i.e. information service for a certain organizational environment, diagnostics of information solutions and tools, information logistics, data management (also in the area of science), and information services (including infobrokering). The term information management appeared in the second half of the 1970s. Since the mid-1990s, along with the growing interest in business information and information activities in various commercial organizations, its popularity also began to increase rapidly, although the content began to blur in connection with the emergence of a new concept of knowledge management. A noticeable phenomenon of the development of modern information management is undoubtedly multidisciplinarity. Information management has its sources in many areas that have traditionally been involved in the acquisition, organization, maintenance and use of documents (including archives and records management) for years. Gradually, research has been contributed by various professional groups related to information technology, database design and development, information systems, information retrieval, information economics, management theory, and organization theory. In the 1990s, the term knowledge management was adopted to mean parts of research focused on human resources and what were termed intellectual 
capital and organizational learning issues, emphasizing the importance of the human factor for the flow of information and knowledge, creating organizational culture, organizational efficiency, etc. In recent years, Personal Information Management, as it is called, has been developing as well. It is focused on analysing behaviour related to information and knowledge management by representatives of various social groups, designing technological tools supporting the management of one's own information and knowledge resources as well as education and acquisition of competencies in this area.

An important place in the areas noted above is occupied by research related to information excess, including scientific information, leading to information overload and searching for information. The history of subsequent "information floods" caused by information overload and tools that were created to mitigate them, as Rheingold wrote (Rheingold, 2012), suggests that the period of information overload after the invention of each radically more effective means of communication seems to initially trigger fear followed by the creation of new information tools and the development of newly enlightened social groups. "At least since the invention of print and complex societies, the amount of information available exceeds the perceptive capabilities of single individuals, so to cope with excess, societies produce collective knowledge management systems. Changes in the knowledge system are always accompanied by an increased sense of crisis and information overload - in this situation the elites are looking for new tools and competencies, which are then subject to democratization and dissemination in society" (Piekarski, 2017, p. 12). Info specialists are not alone in solving problems related to information overload and increasing attention deficit. They are also dealt with by psychologists, IT specialists, communication specialists, media experts and even psychiatrists. The information flood is confronted by the economy of attention. Therefore, more and more often data is presented using visualizations, maps, charts or diagrams, and at least a partial renunciation of natural language in favour of a visual is one of the most spectacular differences between what is traditional (in information science, media studies, journalism, etc.) and what is modern (data engineering, data journalism, etc.).

Searching for information is understood in the information science in two ways: a) in relation to processes, techniques and strategies for quickly and efficiently finding (selecting) relevant information in resources (the context of the information technology used is key here); b) regarding various information behaviours of people who are focused on obtaining the information they need (studies on information users are key here). There is a high level of interactivity between the system and the user, the basis of which is to take into account the dynamics of changes in information needs at various stages of the search process. Information retrieval is 
also the main reference point in information-centred research. The most important research questions that are being sought are: how different users use information systems (research into the use of information and search systems, specific sources of information); how they formulate questions directed to information-retrieval systems (determining information needs); how they strive to obtain the information they need (determining the nature and conditions of information behaviours undertaken); what information competences (knowledge and skills) are necessary for behaviours to lead to success, etc. Many theoretical models have been created regarding this issue, some of which have been implemented in practice (Pulikowski, 2018).

\section{SUMMARY}

Before our eyes, the current research field of information and book studies is changing and being redefined. Both information and book studies must ensure their fully-fledged position in the new discipline, i.e. in media and social communication studies. On the other hand, they must be loyal to social obligations arising from functioning in a specific situation, counting on the reciprocity of specialties co-creating media and social communication studies. Fortunately, the good of the new common discipline does not require us to give up our own specificity and distinctiveness of research issues focused on the book at its various stages of development, libraries and other cultural institutions, and information that plays an increasingly important role in social, scientific, multimedia, and digital communication. There is a need for widespread discussion of the many problems (including the name of the discipline) that arise as a consequence of the merger and creation of a new discipline, involving the book studies and information environment, communication and media studies, and the cognitive sciences. It is a discussion in which science managers in Poland should also be included, because there can also be threads referring to the essence of the academy, the overarching goal of scientific research, or the "terror of performativity" (Lisowska-Magdziarz, 2019), and so forth.

\section{BIBLIOGRAPHY}

Cisek, Sabina (2013). Informatologia w drugim dziesięcioleciu XXI w. Przedmiot, pole badawcze imiejscewsystemienauk. Repozytorium prezentacji, Krajowe Forum Informacji Naukowej i Technicznej, Zakopane, 24-27 września 2013 [online]. Available on: <http://www.ptin. us.edu.pl/konferencje/12forum/repozytorium/Cisek.pdf >.

Cisek, Sabina (2009). Nauka o informacji na świecie w XXI wieku: badania metanaukowe. [online]. Available on : <http://eprints.rclis.org/11098/1/Cisek_in_na_swiecie_eng.pdf $>$. 
Cisek, Sabina (2002). Filozoficzne aspekty informacji naukowej. Kraków, Wydaw. Uniwersytetu Jagiellońskiego.

Głowacka, Ewa (2017). Główne współczesne kierunki badań z zakresu bibliotekoznawstwa na świecie w XXI wieku. In: A. Pulikowski (Ed.), Kultura ksiażki i informacji. Księga jubileuszowa dedykowana Profesor Elżbiecie Gondek (pp. 111-123). Katowice, Wydaw. Uniwersytetu Śląskiego.

Koredczuk, Bożena (2019). Komunikacja bibliologiczna w wybranych systemach komunikacji i ich wpływ na usytuowanie bibliologii w aktualnie obowiązującej klasyfikacji nauk - zarys problemu badawczego. Przeglad Biblioteczny, special edition.

Kowalska, Małgorzata (2017). Altmetria jako przedmiot zainteresowania bibliologii i informatologii. Przeglad Biblioteczny, 85(3), pp. 324-341

Lisowska-Magdziarz, Małgorzata (2019). Media i komunikowanie społeczne: federacja, ale jaka? Dalsze pytania o przyszłość dyscypliny. Studia Medioznawcze, 19 (2), pp. 118-129 [online]. Available on: <https://studiamedioznawcze.eu/index.php/studiamedioznawcze/article/view/104>.

Piekarski, Karol (2017). Kultura danych. Algorytmy wzmacniające uwagę. Gdańsk: Wydaw. Naukowe Katedra.

Pulikowski, Arkadiusz (2018). Modelowanie procesu wyszukiwania informacji naukowej: strategie $i$ interakcje. Katowice: Wydaw. Uniwersytetu Śląskiego

Rheingold, Howard (2012). Net Smart. How to Thrive Online, Cambridge: MIT Press.

Sosińska-Kalata, Barbara (2017). Nauka o informacji wśród nauk o kulturze. In: A. Pulikowski (Ed.) Kultura ksiązki i informacji: Księga jubileuszowa dedykowana Profesor Elżbiecie Gondek. Katowice: Wydaw. Uniwersytetu Śląskiego, pp. 311-325.

Sosińska-Kalata, Barbara (2013). Obszary badań współczesnej informatologii (nauki o informacji). Zagadnienia Informacji Naukowej. Studia Informacyjne, 51(2), pp. 9-41.

Woźniak-Kasperek, Jadwiga (2015). Z głównych problemów samoświadomości informatologii. In: E. Gondek (Ed.) Teoretyczne zagadnienia bibliologii oraz informatologii: studia i szkice (pp. 139-157). Katowice: Wydaw. Uniwersytetu Śląskiego. 